\title{
Semiotic Elements Of Barthesian Model On “Zooey Deschanel” Pantene Shampoo Print Advertising
}

\author{
Juniato Sidauruk $^{1}$, Jimmi ${ }^{2}$, Esi Septiani ${ }^{3}$ \\ ${ }^{1}$ Universitas Bina Sarana Informatika \\ e-mail: juniato276@gmail.com \\ ${ }^{2}$ Universitas Bina Sarana Informatika \\ e-mail: jimmi.jmm@bsi.ac.id \\ ${ }^{3}$ Universitas Bina Sarana Informatika \\ e-mail: esiseptiani@gmail.com
}

\section{Cara Sitasi :}

Sidauruk, J., Jimmi, J., \& Septiani, E. (2019). Semiotic Elements Of Barthesian Model On "Zooey Deschanel” Pantene Shampoo Print Advertising. Wanastra, 11(2), 127-140.

\begin{abstract}
Print advertising contains several elements that can be discussed linguistically. There are semiotic elements commonly found in advertisements. There are lack discussion from researchers deal with semiotic elements in advertisements. There are three advertisements that will be analyzed in this research. The objective of this research is to find out semiotic elements in the Pantene Shampoo print advertising of "Zooey Deschanel" edition. The analysis is focused on semiotic elements by referring to Roland Barthes -- is commonly known as Barthesian Model. Barthes classified semiotic elements into Denotative, Connotative, and Myth. The analysis is presented by using descriptive qualitative method. Barthes' Order of Signification will be the main pattern used to do the analysis. The results indicate that there are some signs found in the advertisements that contain semiotic elements. Eagerly saying that those three advertisements contain all semiotic elements as mentioned on order of signification from Roland Barthes. The writers found 32 signs in all advertisements, Signifier; and Connotative Signifier dominates all signs. The semiotic elements discussion can be used as raw model for next researchs. Beside that, this discussion will inform and helpful to the advertisement producers, and alert them to think of all and consider the semiotic elements in their ads. The creators of the advertisements have to make it easy to understand by the public or target market of the product.
\end{abstract}

Keywords: Print Advertising, Semiotics Elements, Sign, Signifier, Connotative Signifier.

\section{INTRODUCTION}

The print media is one of the media to campaign and offer variety of products. Advertising is a phenomenon of modern business, or the window of a company. It is a bridge to connect the company with the public, especially consumers. Advertising has an order to promote or to service consumer's need. In the mix of promotion, print advertising media reckoned as one of the best approaches to create public awareness of the product. Through advertising, a product can be known, loved, and interested by public. Public can be selected by product segmentation and target of market.

(Procter \& Gamble, 2019) -- P\&G, a company that produces so many beauty products has been able to issue advertisements is quite phenomenal. (Global Cosmestic News, 2015) writes that through one of their advertising are advertisements of Pantene Shampoo products, $\mathrm{P} \& \mathrm{G}$ is able to attract women to use the product, results in improving sales achievement. In the advertising, everything concerning the products is dedicated to the femininity of women. Here seen are there significant role of using signs in the advertisements.

Human's life is filled by signs. Mediated by the signs, the process of life is moved on effectively. People can communicate among others and have better understanding of their environment simultaneously. Therefore, they are homosemioticus. They use codes that have been formed by themselves daily. Such as a saying love of a man to his beloved woman and gives her a beautiful stem of rose. It can be said as sign too.

In interpreting signs, someone needs the knowledge about how sign could be interpreted as well as what is purposed. In linguistics, it is called as Semiotics. Semiotic analysis may be considered a subset of content analysis; it studies how signs and symbols generate meaning (Rose, 2001). In other words, the signs and symbols must be the main consideration in its way to generate meaning. Meaning must be explored in a more detail way. Barthes (2005) in 
(Kükürt, 2016, p. 2172) states that each object has a meaning which transcends its use. There is no object that escapes from having meaning. It means that print advertising as an object has meaning that can be discussed too. In the context of semiotics, signs in the print advertising will be analyzed more deeply, so the writers can get better interpretation from all display of the advertising. The writers choose Barthes theory as Barthes is one of people credited with using structuralism and semiotics as a way to analyze advertisements. Barthes stated that marketing instruments are divided into two levels. The first is the "denotative" level where sign are used to create personality for a product and the second is "connotative" level, which reveals the hidden meaning of the images, text, and sounds used.

The analysis will be reviewed and focused on the element of semiotics from Roland Barthes theory, that is denotative, connotative, and myth. Peirce in (Chandler, 2007, p. 13) said, "We think only in sign". Sign System includes words, images, numbers, and objects. These signs have meaning only because people have agreed upon and use this shared meaning. He added that "Nothing is a sign unless it is interpreted as a sign". Anything can be a sign as long as someone interprets it as 'signifying' something - referring to or standing for something other than itself.

Peirce in (Chandler, 2007, p. 30) clarifies that there is triangular theory of meaning which consists of three main elements, namely the sign (sign), object, and interpretant. Signs are physical objects that can be captured by the five human senses and is something that refers to (represent) something other than the sign itself. Peirce mark consists of the symbol (the marking of the deal), Icon (the marking of the physical representation) and Index (the marking of cause-effect relationships). This is called object. Object reference mark or reference mark is the social context that becomes the reference of a sign or something referred sign. Interpretant is the concept of thinking of the people who use the sign and lowered it to a particular meaning or meanings in someone's mind about the object that is referenced a sign. The important thing in the process of semiosis is how the meaning emerges from a sign when the sign was used by people to communicate.

In tune to Peirce, Jacobson in (Chandler, 2007, p. 31) comments that for Peirce "The meaning of the sign is the sign it can be translated into". Saussure in (Chandler, 2007, p. 17), "The signifier and the signified is unity, inseparable, like two sides of a sheet of paper". (Saussure, 1985) divides linguistic signs into two components--the signifier (the sound, image, or word) and the signified, which is the concept the signifier represents, or the meaning. Thus, there are two things that must be focused and identified, the signifier and the signified.

As (Berger, 1990) points out, the problem of meaning arises from the fact that the relation between the signifier and the signified is arbitrary and conventional. In other words, signs can mean anything, and they can mean different things to different people. The arbitrariness is true in most written and spoken language; however it is clear that visual signs are not arbitrary.

Saussure in (Chandler, 2007), "The sign is composed of: The sounds and images, called the signifier, and the concepts of sounds and images, called signified". In communicating, a person uses a sign to send the meaning of objects and other people will interpret these signs. Signifier and signified must be identified in making analysis. Objects for Saussure is called "referent".

Barthes in (Chandler, 2007), in his theory of semiotics develops into two levels of signified, "namely the level of denotation and connotation. Denotation is signified level that explains the relationship signifier and signified in reality, generate meanings explicit, direct, and certainly. Connotation is signified level that explains the relationship signifier and signified in which to operate meaning that is not explicit, indirect, and uncertain". Barthes is the successor of Saussure's theory. Saussure interested in how complex of sentence formation and how the forms of determining the meaning of a sentence, but Saussure is not too interested in the fact that in the same sentence may convey different meanings to different people on different situation.

Barthes forward these ideas by emphasizing the interaction between text with personal and cultural experience of its users, the interaction between the conventions in the text to the conventions experienced and expected by users. Barthes idea is known as the "order of signification", including denotation (meaning actually fit the dictionary) and connotation (double meaning born of cultural and personal experience) (Barthes in (Chandler, 2007, p. 139). This is where the point of difference Saussure and Barthes, although Barthes still use the term signifier-signified that carried by Saussure.

Barthes in (Chandler, 2007) also looks at other aspects of signified, that is "myth" that marks a society. "Myth" by Barthes in (Chandler, 2007, p. 143 ) is laid on the second level of tagging, so after forming the system of sign-signifier-signified, the sign will be a new sign which then has a second signified and establish a new sign. So, when a sign has connotations meaning and evolved to be 
denotation meaning, the meaning of denotation will be a myth.

Eco in (Oswald, 2012) proposes "Semiotics is a social science discipline that takes into account "everything that can be taken as a sign"'. A related term, semiosis, defines the process of meaning production. A sign, simply stated, is something that stands for something else, and semiosis is the cognitive activity that underlies communication activities, whether verbal or nonverbal. Eco in (Jamani, 2011) expands Peirce's notion of sign and describes a sign as "everything that, on the grounds of a previously established social convention, can be taken as something standing for something else". Eco illustrates this with the term "dog" - the term "dog" does not refer to a specific, real dog in the room; it refers to all dogs in the world which is a class or set that cannot be perceived as a real object by the senses. In tune to Jamani, (Tsotra, Danai., Marius Janson, Dubravka Cecez-Kecmanovic, 2004, p. 2411), also quote's Eco's idea (1976) that "semiotics concerns everything that can be perceived as a sign." Signs constitute printed and spoken words, images, sounds, gestures, and objects. Individuals interpret signs as "signifying something." Thus print advertising has the semiotic elements as it contains images and objects. (Sidauruk, 2010) excerpts that semiotics has possibility to be sought through an approach socially oriented and interpretative when focusing on the dynamic nature and transformative of signs following the post-structuralism an epistemic postmodernism.

Eco in (Jamani, 2011) states that "Every attempt to establish what the referent of a sign, forced us to define the referent in terms of an abstract entity which moreover only a cultural convention". Eco sees semiotics object as the content - a cultural unit conventionally assigned by society basedon a system of rules or codes. The perspective of the referent as content fits well with scientific knowledge where referents are often abstract concepts such as "force" and "energy". Eco in (Jamani, 2011, p. 194) suggests that the interpretant can also take on many forms. For example, the word "property" (sign/signifier) is used to signify a characteristic quality when used in relation to a physical object or it could signify an object such as owned land or realestate. Signs therefore do not represent or communicate one single meaning or interpretation.

Additionally, Eco asserts that the meaning or interpretant of a sign can be another sign in another semiotics system (e.g., a drawing corresponding to a word), a definition in terms of the same semiotics system (e.g., "salt" signifies "sodium chloride"), an emotive association (e.g., "dog" signifies "love"), or a translation into another language. (Danesi, 2007, p. 16), "All signification (be it denotative or connotative) is a relational and associative process that is, signs acquire meanings not in isolation, but in relation to other signs and to the contexts in which they occur". Furthermore, (Danesi, 2007) asserts that denotative meaning points out or identifies something (e.g., object, content), whereas connotative meaning includes all other senses including emotional ones that something elicits For example, the word "dog" refers to a four-legged animal kept as a pet (denotative meaning) and also conjures the emotion of miserable when used as "a life like a dog" (connotative meaning).

Based on the background described above, problem in this article are to find out 1) Semiotic elements in Shampoo Pantene print advertising of "Zooey Deschanel" edition; 2) whether or not that all semiotic elements found in the Pantene Shampoo print advertising of "Zooey Deschanel" Edition.

The writers will limit the discussion of the Pantene Shampoo print advertising "Zooey Deschanel" edition to know the semiotic elements of the advertising by referring to Roland Barthes' theory (1915-1980) or commonly known as Barthesian Model.

\section{RESEARCH METHODOLOGY}

The writers use descriptive qualitative method. The object discussion will be identified by focusing on the sign, collected signs on the advertising, analysis on denotative and connotative meaning based on Roland Barthes theory, moreover identify the myth.

The writers specified them and read some literatures on semiotic in advertisements and Roland Barthes theory.

The writers choose the object or advertisements that will be analyzed. The advertisement is taken from (Brown, 2012). Then, The writers are looking for and collecting the data Pantene Shampoo Print Advertisings by reading and identifying, signing, grouping the signs, finding and writing data needed, and interpreting the meaning of the data. The unit of analysis in this research is Pantene Shampoo print advertisings. Those three advertisements are taken from the website of Pantene Shampoo http://pantene.com/en-us.

Print advertisements are only effective when people see them. When people browse through newspapers and publications, these advertisements should grab the attention of the potential customer. Therefore, these advertisements should be created in such a 
manner that they can hold the attention of the customer to some extent. Usually a team of individuals is required in order to design the advertisements.

Related to semiotics signification, advertisement contains more than a sign. It consists of the language element which arranged from a signifier or the material element of the advertisement showed as picture, photo, and illustration and a concept of signified and the meaning beyond it signifier. These structural elements of advertisements are used to show a reality or even falsifying the reality of the advertisement. As referred to (MSG, 2019), "Advertisement is indispensable for both the sellers and the buyers. However, it is more important for the sellers. In the modern age of large scale production, producers cannot think of pushing sale of their products without advertising them".

In analyzing the semiotic elements in the ads, it is better to present some theoretical background. Semiotic is a field of study involving many different theoretical stances and methodological tools. Semiotics is the study of how people make meaning through both linguistic and non-linguistic ways. It is a philosophical theory concerned with understanding how people use signs and symbols in meaningmaking.

In this research writers will apply the Barthesian Model. "Barthesian Model" is developed by referring to Significant-Signifie theory from Saussure to be a theory of grammar and its connotation meaning. The significant term was changed to be expression (E) and the signifie changed to be content (C)" (Akmal, 2008). "Moreover, Barthes said there must be a relation (R) between $\mathrm{E}$ and $\mathrm{C}$ or certain relation. Thus, it can form a sign. Barthes also took over the concepts of denotation, connotation, and metasemiotics from Hjemsleves. Typically, Barthes also changes Hjemsleves term of metasemiotics into metalanguage. As for Hjemsleves, every system for Barthes too, is language".

Interpreting sign can occur in two levels. There are primer (denotation) and then secondary level which is developed into $\mathrm{E}$ (metalanguage) and $\mathrm{C}$ (connotation). Metalanguage can occur if there is there is same $\mathrm{E}$ and $\mathrm{C}$ development in the secondary and connotation in a culture. It is the value which is given by the interpreter of sign to the sign. Barthes describes connotation as the C's width of some signs so that the sign have a new $\mathrm{C}$.

\section{a. Denotation, Connotation, and Myth}

For Barthes in (Chandler, 2017) connotation is the "tone" of a text, the manner which has been decorated. In the final analysis, the signified of a "connotative sign" is for Barthes the "fragment of an ideology", the signified, in turn, a "rhetoric", both going back to a "real system" via metalanguage obviously even here no differences made between communication and indication.

Barthes used the example of photography to demonstrate denotative. The photograph denotes what was in front of the camera when image was captured. But who the image is photographed, and what abstract values may be associated with the resultant picture, and are a matter of connotation. A photograph of a face denotes that face, but what is connoted will depend on agreement of photography (surveillance, fashion, news, art) and on stylistic manipulation of composition, color, etc. it is the same face can connote "criminal", "beauty", and "supermodel".

The mythical level of signification can also be turned the ideological at this level, signification is depend on the shared cultural values and beliefs. Consider the use of images of countryside in advertising. Signification here depends on the myth or ideology that opposes city and country; the country is signified as more pure and innocent than the urban lifestyle. Such as myths are specific to certain cultures, and they are arguable, "countryside" may connote something quite different to a confirmed city-dweller. Although the process of signification is universal, the meanings that are generated in the process will be culturally specific.

\section{b. Barthes Reading Photograph}

Barthes uses Myth on his semiotics analysis about culture and any ideological critic. It can be found in many mass cultural products which have created the language as the communication such as the people's myth today. It is produced through mythological treasure like magazine, television, film, advertisements and many more photographs.

The myth's analysis was focused on the second level of the semiotics system. It is uneasy because what creator see, listen and read is the first level of the semiotics system. Therefore, myth analysis must be directed to the second level of the semiotics system by seeing at the connotation on the signification system on the connotation level. To make it more understandable, Barthes produced map of sign function:

Table 1. Barthes' Second Orders of Signification (Chandler, 2007)

1.Signifier $\quad 2$. Signified 
3. Denotative Sign

\section{Connotative Signifier 5. Connotative Signified}

\section{Connotative Sign}

From the table above, the denotative sign (3) is made from the signifier (1) and the signified (2). Both of them produce the denotative sign which is also being the connotative signifier (4) on the second level of semiotics system. The connotative signifier must engender a connotative signified (5) to produce a connotative sign (6). That is where the kind of systematic approach to signs that Barthes wished to persue becomes very problematic (Chandler, 2007). The connotation works on the subjective level that makes its present cannot be realized. The reader can read easily the connotative meaning as the denotative fact. Therefore, one of the semiotics analysis aims is to furnish the analysis method in order to handle the misreading.

In handling the misreading of the advertisements photograph, Barthes distinguished the signs into two important parts that have to be underlined. They are verbal parts and non-verbal signs. The verbal sign is of course the text of the advertisement. It can be the name or the slogan of the product or people, information about something, persuasion sentences, or anything else in text form. The non-verbal signs are the signs which appearances are aimed to support the verbal part in order to be an interesting package of advertisement. Both have deep meaning that can produce message to reader, not only as a compliment. Those are:

\section{The use of color}

The using of color is a vital aspect of art direction in printed media and billboard advertisements. Colors are also as logos which arranged by the advertising maker to increase the reader's recognition, to make the link between the brand (the picture) and the message. Color is a meaningful constant for sighted people and it is a powerful psychological tool (Matikas, 2009).

Black : is color of authority and power, stability and strength. It is also the color associated with intelligence (doctorate in black robe, black horn rimmed glasses). Black clothes make people appear thinner. It is a somber color sometimes associated with evil (the cowboy in the black hat was almost always the "bad guy"). In the western hemisphere black is associated with grieving. Black is a serious color that evokes strong emotions, it is easy to overwhelm people with too much black.
White, for most of the world this is the color associated with purity (wedding dresses), cleanliness (doctors in white coats) and the safety of bright light (things go bump in the night...not the bright sunshine). It is also used to project the absence of color, or neutrality. In some eastern parts of the world, white is associated with mourning. White associated with creativity (white boards, blank slates). It is a compression of all the colors in the color spectrum.

Gray : is most associated with the practical, timeless, middle-of-the road, solid things in life. Too much gray leads to feeling mostly nothing, but a bit of gray will add that rock solid feeling to your product. Some shades of gray are associated with old age, death, taxes, depression or lost sense of direction. Silver is an off-shoot of gray and often associated with giving a helping hand, strong character.

Red, is often used to catch attention where the eyes look first. Red is color of energy. It is associated with movement and excitement. People surrounded by red find their heart beating a little faster and often report feeling a bit out of breath. It is also symbol of life because our blood is red.

Blue, is the world color. When one see at the blue color, people suddenly feel calm and restful but some dark blue can describe a cold and uncaring message. Over the ages blue has become associated with steadfastness, dependability, wisdom and loyalty.

Purple, is the color of wealth, prosperity, rich sophistication. This color stimulated the brain activity used in the problem solving. Be careful in using purple can lend an air of mystery, wisdom, and respect.

Brown, is most associated with reliability, stability, and friendship. It is also associated with things being natural or organic

\section{The use of music}

Music or sound is usually used in television and radio advertisement. It can add the sensory dimension of advertising and branding and provide an emotional or mood setting which can evoke a variety of feelings.

\section{The use of animation}

Usually, the advertisements makers use this part as the creative technique. They use some graphical design technology to sell their ware in the advertisements and also to attract the reader (customer) attention to be the interesting picture. 


\section{Print Advertising}

The word advertising comes from the Latin word "advertere" means "to turn the minds of towards". (Stantons, 2006) says, "Advertising consists of all the activities involved in presenting to an audience a non-personal, sponsor-identified, paid-for message about a product or organization". So, advertising is process of offering something to the audience that ends with paying what is offered. (Schement, 2002) says, "Advertising is persuasive and virtually impossible to escape". The advertising is to grab public attention and seems no way out of the ads.

As referred to (MSG, 2019), "Print advertising is a widely used form of advertising". These advertisements appear in newspapers or magazines and are sometimes included as brochures or fliers. Anything written in the print media to grab the attention of the specific target audience comes under the purview of print advertising. People who read newspapers or other publications have a tendency to browse the print advertising that they come across. The decision to buy the product might not be instantaneous, but it does settle down in their subconscious mind.

\section{FINDING AND RESULT}

\section{Semiotic Elements on Pantene Shampoo of “Zooey Deschanel” Edition by Barthesian Model.}

The writers use Pantene Shampoo print advertisement as the object of the research. The data are collected from Pantene Shampoo collections that have identical characteristics as sign. The data of the advertisement will be presented using the analysis of Barthes's Map of sign functioning as follow:

Table 2. Second Orders of Signification (Chandler, 2007)

\section{Signifier 2. Signified}

3. Denotative Sign

\section{Connotative Signifier 5. Connotative Signified}

\section{Connotative Sign}

The writers divide the research findings abd discussion into two sections in every advertisement, they are: data description and data analysis.

\section{A. Semiotic Elements on Ads 1}

In this section the writers will describe what is the sign that contain in the advertisement element by divided the sign into two parts: verbal and nonverbal.

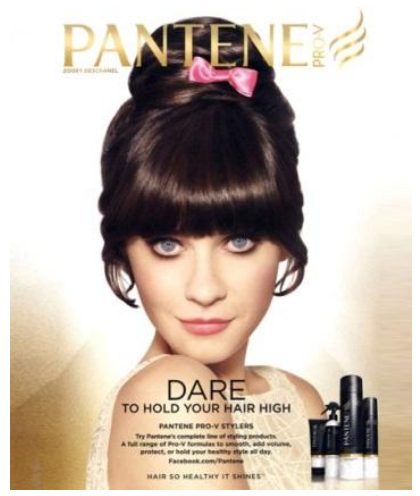

Figure 1. Pantene Shampoo Advertisement "Dare To Hold Your Hair High

\section{Data Description}

Table 3. Verbal and Non-verbal Sign Description of Pantene Shampoo Advertisement 1

\begin{tabular}{ll}
\hline \multicolumn{1}{c}{ Verbal Sign (V) } & Non Verbal Sign (NV) \\
\hline Phrase "DARE TO & Figure of "Hair Tassel" \\
HOLD YOUR HAIR & \\
HIGH" & Figure of woman \\
\hline $\begin{array}{l}\text { Phrase "PANTENE } \\
\text { PRO-V STYLERS" }\end{array}$ & \\
\hline $\begin{array}{l}\text { Sentence "Try Pantene's } \\
\text { complete line of styling } \\
\text { products" }\end{array}$ & Figure of Ribbon \\
\hline $\begin{array}{l}\text { Sentence "A full range of } \\
\text { Pro-V formulas to } \\
\text { smooth, add volume, } \\
\text { protect, or hold your } \\
\text { healthy style all day" }\end{array}$ & \\
\hline $\begin{array}{l}\text { Phrase "HAIR SO Figure a set of products } \\
\text { HEALTHY IT SHINES" }\end{array}$ & \\
\hline
\end{tabular}

\section{Data Analysis}

This section is analysis of what have been describe in the data description of Advertisement 1, in this analysis the writers use (1) as sign of Signifier, (2) as sign of Signified, (3) as sign of Denotative Sign, (4) as sign of Connotative Signifier, (5) as sign of 
Connotative Signified, and (6) as sign of Connotaive Sign, the data analysis are below:

The analysis begins with the understanding of the letter PANAENE? (1). As verbal sign, it connotes the identity of the product (4). The position of the text is in the center of the advertisement, it has a purpose to take public attention (5), moreover the text complete with bold forming and gold color (1), it shows that the text is one of the eye-catching object (4).

Symbol (1) in the letter PANTEDE? is to shows that the product is hair treatment product (4). The figure explain that the hair will grow health and volume (5). The colour (1) of the figure is explain "live" colour, its bright and looks grow (4).

The next analysis is figure of beautiful woman (1). As non-verbal sign it is symbol of beauty (4). The figure of beautiful woman that support with a cheerful face (1) indicates a confident expression (4), it will make sense if someone have a strong and healthy hair, someone can style it like they want and of course will cause our self-confidence (5). In the figure can see that the hair is styled, it shows that the product is actually has an effect to make the hair can style. The white color (1) of model's clothes indicate of courage (2), because indirectly it guarantee the product that the hair is would not fall (5). In next level, woman has their own position as the symbol of beauty, so without the public read or know about details of the product, they have had their own perception about the product (6).

The phrase "DARE TO HOLD YOUR HAIR HIGH" (1) has meaning that the product has a benefit to make the hair healthy and strong (3), because it has challenge to take the hair high, it means that the hair can style (3), for example the hair can hold or tassel highly. The capital letter of the text (1) explain the main message of the advertisement (2), it persuade the public to see and read the text on their first sight (4), and after that the public will create their first impression about the product (5).

The phrase "Pantene Pro-V Stylers" (1) explain that the product is special edition for hair stylers (3) or recommended for people who like to style and change their hair (3). As verbal sign it also shows that Pantene Shampoo has more than one edition of hair treatment. The position and form of the letter is not too dominant (1), it means that the phrase is just to support the meaning of the main sign (4).

The next sign is phrase "Try Pantene's complete line of styling product" (1), it means that the producer persuade the public to taste the edition of the product (3), and it has meaning that the producer wants to show something that contain in the product, the producer wants the public prove the function of the product (3).

The sentence "A full range of Pro- $\mathrm{V}$ formulas to smooth, add volume, protect, or hold your healthy style all day" (1), has original meaning that the product is contain rich of Pro- $\mathrm{V}$ formulas to make hair smooth, increase the hair volume, protect the hair from free radicals, or keep the hair healthy although it style all day (3). It connotes that the product is a good product (4), not only because it made from good formulas, but also because the product offered so many function for the hair. The sentence will create the perception that a good product always made from good formulas and have so many good functions for the user (5).

The next sign is the phrase of social media site "facebook.com/ Pantene"(1), it explains that the public can search the information about the product in the other media (3). It connotes modern life (4), because it not manually anymore, it serves in the social media, which is more selected by publics.

The next sign is figure of hair tassel (1). It shows that the product can make the hair strong, so it can tassel highly (2). The hair in the figure is look glowing (1), it emphasize the message that if someone has a strong and beautiful hair it will look shine and glowing (2).

The figure of ribbon (1) on the advertising is symbol of feminity and flabbiness (4), more over the figure using "pink" color. The combination between white and red color has a deep meaning as symbol of concern, calm, flabbiness and togetherness (4). The position of the figure is to take attention the main message of the advertisement and shows the function of the product (5).

Figure a set of product (1) has purpose to emphazise the function of the product (4), it convinces that the product is hair treatment product (5). The figure is consist of various product (1), it shows that each product is has its own function (4), and each product support another product function. The possition of the figure is in the edge of the advertising (1). It explain that the figure is not the main message which want to delivered by the producer (2). Beside that the color gold-white in the background (1) of the advertisement make a glamour sense and indicate the imagery of beauty (4).

Thus, this advertisement shows that "Strong and healthy is beautiful, the figure of beautiful woman and her expression determine the imagery of the 
advertisement, because some phrases or other sign only emphasize the implicit meaning of the figure.

\section{B. Semiotic Elements on Ads 2}

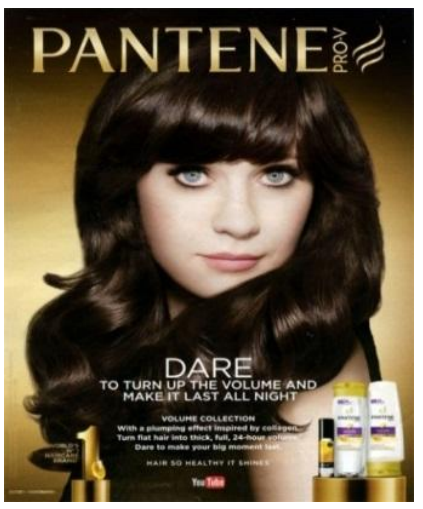

Figure 2. Pantene Shampoo Advertisement "Dare To Turn Up The volume and make It Last All Night"

\section{Data Description}

Table 4. Verbal and Non-verbal Sign Description of Pantene Shampoo Ads 2

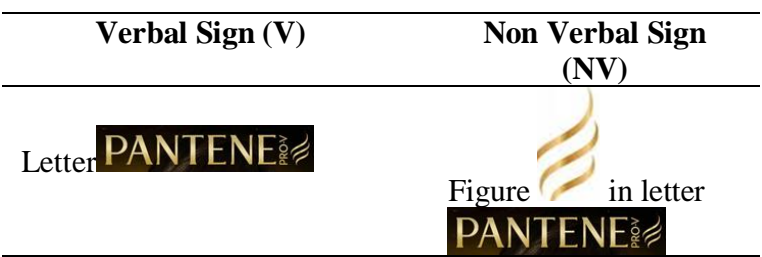

Phrase "DARE TO TURN UP

Symbol

THE VOLUME AND MAKE IT LAST ALL NIGHT"

\section{You Tube}

\begin{tabular}{ll}
\hline $\begin{array}{l}\text { Phrase "VOLUME } \\
\text { COLLECTION" }\end{array}$ & $\begin{array}{l}\text { Figure "1" and text } \\
\text { "World's No.1 } \\
\text { Haircare Brand" }\end{array}$ \\
\hline $\begin{array}{l}\text { Sentence "With a plumping } \\
\text { effect inspired by collagen. } \\
\text { Turn flat hair into thick, full, } \\
\text { 24-hour volume" }\end{array}$ & Figure of woman \\
\hline $\begin{array}{l}\text { Sentence "Dare to make your } \\
\text { big moment last" }\end{array}$ & Figure a set of product \\
\hline $\begin{array}{l}\text { Phrase "HAIR SO HEALTHY } \\
\text { IT SHINES" }\end{array}$ & \\
\hline
\end{tabular}

\section{Data Analysis}

The analysis of the advertisement 2 begins from analysis of the letter PANTENE: (1). As a verbal sign, it connotes the identity of the product (4) the position of the text (1) is in the center of the advertisement, it has a purpose to take public attention (4), moreover the text complete with bold forming and gold color (1), it shows that the text is one of the eye-catching object (4).

Symbol (1) in the letter PANTENE⿳亠丷厂犬 is to show that the product is hair treatment product (4). The figure explain that the hair will grow health and volume (5). The colour (1) of the figure is explain "live" colour, its bright and looks grow (4).

The next sign is figure of beautiful woman (2). As non-verbal sign, it connotes the symbol of beauty (4). There are black and volume hair on the figure (1), it indicate or connotes the healthy hair, black (1) means brave and strong (4), while volume hair (1) indicate health and free (4). Shortly, strong and black are beautiful. The sharp eyesight (1) explains the confidence expression (4), it means convince to walk forward and brave to pass anything in the future (5).The hair in the figure looks glowing (1), it emphasizes the message that if someone has a healthy and beautiful hair it will look shine and glowing (2). In next level, woman has their own position as the symbol of beauty, so without the public read or know about details of the product, they have had their own perception about the product (6).

The phrase "DARE TO TURN UP THE VOLUME AND MAKE IT LAST ALL NIGHT"(1). As the verbal sign it have original meaning "Challenge to increase the volume and keep it until the end of night (3). It means that the product has a challenge the public to prove that the product able to turn up or add the hair volume and keep it all day until the end of night (3). It00-2 connotes to emphasize the message which is illustrated in the figure of beautiful woman (4). The bold letter (1) of the phrase shows the persuasion from the producer (4). They want the public to buy and try the product (5).

The phrase "Volume collection" (1) explain that the product is Pantene volume treatment edition (3). It connotes the slogan of the collection (4). The phrase is indicated and emphasize that the product (Pantene Shampoo) have various editions (4).

The next sign is sentence "With a plumping effect inspired by collagen. Turn flat hair into thick, full, 24-hours volume" (1), the sentence has original meaning that the product complete with plumping effect that adopt from the function of collagent which is an abundant element in human body (3) It will change the thin hair to be volume, all day as long as 24 hours, it will stay volume (3). The phrase connotes the good product (4), because it completed 
with good formulas, adopted from beneficial ingredient and has so many functions (5).

The phrase "HAIR SO HEALTHY IT SHINES" (1) is the slogan of the product (4). The phrase has meaning that the product can change the hair to be health, when the hair health it will look like shines (3). The phrase is used by Pantene as their "jargon" (4), that's indicates the producer guarantee about the function of the product (5).

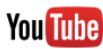

symbol (1) explains that the advertisement can browse from the other media (3). It connotes modern life or up to date (4), the advertisement can access from social media which is now days more interesting than the other media (5). Indirectly, the sign shows that the information of the product is not limit on the print advertisement, but there are still many others information that publics will get in the social media especially you tube (5).

The next sign is letter "1" with text "World's No. 1 Hair Care Brand" (1). This verbal and non-verbal sign actually have same mean, it will explain that the product is one of the best product in the world, especially for Hair Care Brand (4). Basically, publics need a good product and publics always interest with something which has a good confession from many peoples. It is one of the producer tricks to persuade the public, so they buy the product offered (5).

Figure a set of product (1) is has purpose to emphazise the function of the product (4), it convice that the product is hair treatment product (5). The figure is consist various of product (1), it shows that each product is has its own function (4), and each product support another product function. The possition of the figure is in the edge of the advertising (1). It explain that the figure is not the main message which want to delivered by the producer (2). Beside that the color gold-blackin the background (1) of the advertisement make a glamour sense and indicate the imagery of strong and elegant (4).

Thus, this advertisement shows that the product has a good effect to the public, imagery the effect of the product reflect in the figure of woman, and its depend on how the model express the face and play the character.

\section{Semiotic Elements on Ads 3}

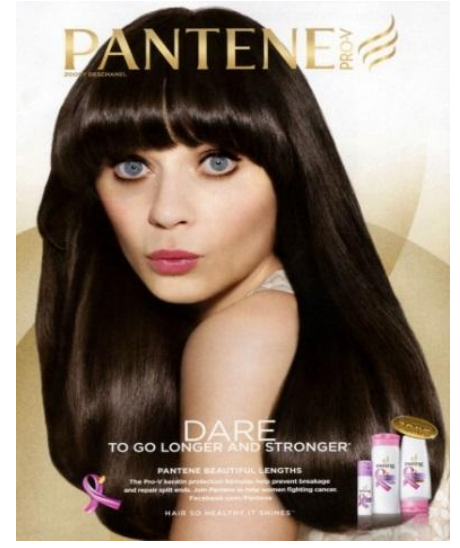

Figure 3 Pantene Shampoo Advertisement "Dare To Go Longer and Stronger"

\section{Data Description}

Table 5. Verbal and Non-verbal Sign Description of Pantene Shampoo Advertisement 3

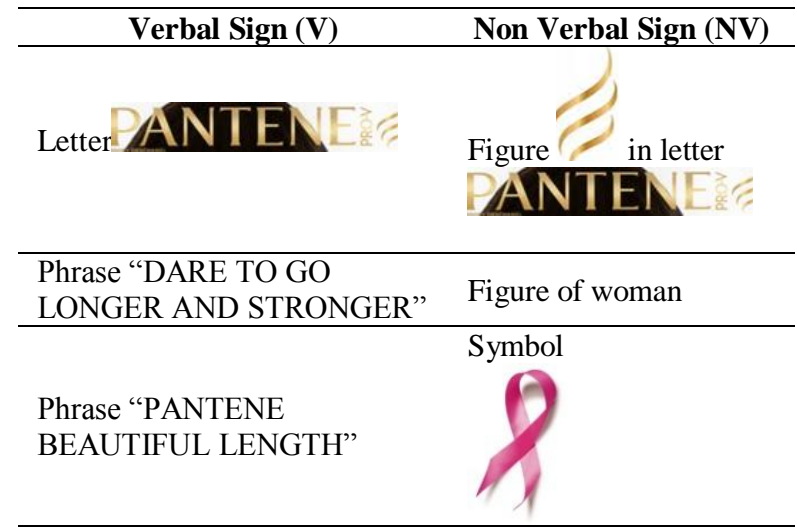

Sentence "The Pro-V Keratin

protection formulas help

prevent breakage and repair

Figure a set of products

split ends"

Sentence "Joint Pantene to

help woman fighting cancer"

Phrase "HAIR SO HEALTHY

IT SHINES"

Phrase

"Facebook.com/Pantene"

\section{Data Analysis}

The analysis of advertisement 3 begins with analysis of the letter PANTENE (1). As non-verbal sign, it connotes the identity of the product (4). The position of the text is in the center of the advertisement (1), it have a purpose to take public attention (4), moreover the text complete with bold forming and gold color (1), it shows that the text is one of the eye-catching object of the advertisement (4). 
Symbol (1) in the letter PANTENE is to shows that the product is hair treatment product (4). The figure explain that the hair will grow health and volume (5). The colour (1) of the figure is explain "live" colour, its bright and looks grow (4).

The next analysis is figure of beautiful woman (2).As non-verbal sign it connotes the symbol of beauty (4). Figure of the woman complete with long, straight, and black hair (1), it is indicate the healthy hair (4), long-straight-black associated strong and unbreakable (4). The expression of the model (1) shows that she has something that proper to share with the publics, it is connotes confidence expression (4). The white clothes of the model (1) explain calmly and neutral (4), it make sense the purity and emphasize the beauty image (5). In next level, woman has their own position as the symbol of beauty, so without the public read or know about details of the product, they have had their own perception about the product (6).

The phrase "DARE TO GO LONGER AND STRONGER" (1) is verbal sign that identify the product edition (3). The letter "DARE" with larger form and bolder than the others (1), it means to emphasize the next (4) phrase "TO GO LONGER AND STRONGER", it has original meaning that the it is challenge to make hair grow long and strong (3).

Phrase "PANTENE BEAUTIFUL LENGTH" (1) in the advertisement explain that the product is collection of Pantene Shampoo (3), it connotes that the product is especially to make the hair grow long (4).

Sentence "The Pro-V Keratin protection formulas help prevent breakage and repair split ends"(1)have original meaning that the product complete with Pro$\mathrm{V}$ formula that able to prevent breakage and able to repair hair demage (3). It connotes that the product is made from a best formula (4). It automatically will make sense that the product is have a good effect to the hair (5).

Sentence "Joint Pantene to help woman fighting cancer"(1) means that the product has a contribution on help woman figthing cancer. (3) It connotes that the product is symbol of motivation in cancer (4).

The phrase "HAIR SO HEALTHY IT SHINES" (1) is the slogan of the product (4). The phrase has meaning that the product can change the hair to be health, when the hair health it will look like shines (3). The phrase is used by Pantene as their "jargon", that indicate the producer guarantee about the function of the product (5).
The next sign is the phrase of social media site "facebook.com/Pantene" (1), it explain that the public can search the information about the product in the other media (3). It connotes modern life (4), because it not manually anymore, it serves in the social media, which is more selected by publics (5).

The next sign is symbol (1), it is symbol of cancer (3). It means that the product has contribution on fighting cancer (4).

Figure a set of product (1) is has purpose to emphazise the function of the product (4), it convice that the product is hair treatment product (5). The figure is consist various of product (1), it shows that each product has its own function (4), and each product support another product function. The possition of the figure is in the edge of the advertising (1). It explains that the figure is not the main message which want to delivered by the producer (2). The pink color of the package is symbol of feminity (4), and make sure that the product is has contribution on woman life in giving motivation on fight cancer (5). The other implicit sign is the background of the advertisement. The creamy color is indicate calmly and elegant (4). Indirectly, it explain that woman have to be an elegant and calmly (5).

Thus, this advertisement shows that the product is has a good effect to the public, imagery the effect of the product reflect in the figure of woman, and its depend on how the model express the face and play the character.

\section{Findings of Semiotic Elements on the Advertisements}

In this section, the writers will present the table to know what does semiotics element which is found on the advertising. Based on the analysis in 3.1, (1) as sign of Signifier, (2) as sign of Signified, (3) as sign of Denotative Sign, (4) as sign of Connotative Signifier, (5) as sign of Connotative Signified, and (6) as sign of Connotaive Sign, here is the table:

\section{A. Semiotic Elements on Ads 1}

Table 6. Data Semiotic Elements of Ads 1 


\begin{tabular}{|c|c|c|c|c|c|c|}
\hline Sign & 1 & 2 & 3 & 4 & 5 & 6 \\
\hline $\begin{array}{l}\text { Phrase “DARE TO HOLD } \\
\text { YOUR HAIR HIGH” (V) }\end{array}$ & + & + & + & + & + & - \\
\hline $\begin{array}{l}\text { Phrase "PANTENE PRO-V } \\
\text { STYLERS" (V) }\end{array}$ & + & - & + & + & - & - \\
\hline $\begin{array}{l}\text { Sentence "Try Pantene's } \\
\text { complete line of styling } \\
\text { products" (V) }\end{array}$ & + & - & + & - & - & - \\
\hline $\begin{array}{l}\text { Sentence "A full range of Pro- } \\
\text { V formulas to smooth, add } \\
\text { volume, protect, or hold your } \\
\text { healthy style all day" (V) }\end{array}$ & + & - & + & + & + & - \\
\hline $\begin{array}{l}\text { Phrase "HAIR SO HEALTHY } \\
\text { IT SHINES" (V) }\end{array}$ & + & - & + & + & + & - \\
\hline $\begin{array}{l}\text { Letter PANTENE⿺辶⿱丷天) } \\
(\mathrm{V})\end{array}$ & + & - & - & + & - & - \\
\hline $\begin{array}{l}\text { Figure in letter } \\
\text { PANTENE亳 }\end{array}$ & + & - & - & + & + & - \\
\hline Figure of "Hair Tassel" (NV) & + & + & - & - & - & - \\
\hline Figure of woman (NV) & + & + & - & + & + & + \\
\hline Figure of Ribbon (NV) & + & - & - & + & + & - \\
\hline Figure a set of products $(\mathrm{NV})$ & + & + & - & + & + & - \\
\hline TOTAL & 11 & 4 & 5 & 9 & 7 & 1 \\
\hline
\end{tabular}

Notes: $\quad \mathrm{V}=$ Verbal Sign

$$
\begin{aligned}
\text { NV } & =\text { Non-Verbal Sign } \\
+\quad & =\text { Positive } \\
-\quad & =\text { Negative }
\end{aligned}
$$

From table 6, there are 11 signs of Signifier, 4 signs of Signified, 5 signs of Denotative, 9 signs of Connotative Signifier, 7 sign of Connotative Signified, 1 sign of Myth. From the data above, the writers can conclude that Signifier dominates the sign, and Connotative Signifier is on the second level followed by Connotative Signified because basically every sign has implicit meaning. Then myth is only found in the figure of woman. While Signified only found in 4 signs and Denotative Sign found in 5 signs.

\section{B. Semiotic Elements on Ads 2}

\begin{tabular}{|c|c|c|c|c|c|c|}
\hline Sign & 1 & 2 & 3 & 4 & 5 & 6 \\
\hline $\begin{array}{l}\text { Phrase "DARE TO TURN UP } \\
\text { THE VOLUME AND MAKE } \\
\text { IT LAST ALL NIGHT" (V) }\end{array}$ & + & - & + & + & + & - \\
\hline $\begin{array}{l}\text { Phrase "VOLUME } \\
\text { COLLECTION" (V) }\end{array}$ & + & - & + & + & + & - \\
\hline
\end{tabular}

Table 7. Data Semiotic Elements of Advertisement 2

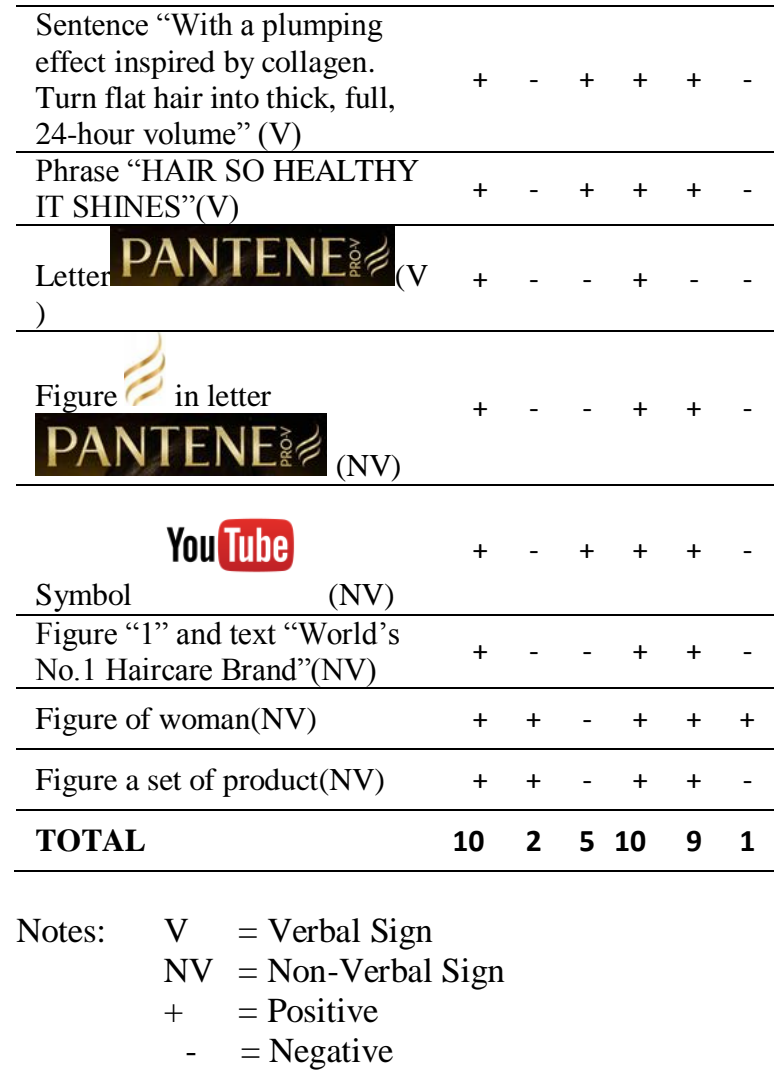

Based on Table 7, there are 10 signs of Signifier, 2 signs of Signified, 5 signs of Denotative Sign, 10 signs of Connotative Signifier, 9 signs of Connotative Signified, and 1 sign of Connotative Sign. From the data above, it can be concluded that Signifier and Signifier are dominate the sign, and Connotative Signifier is on the second level then followed by Connotative Signified because basically every sign has implicit meaning. Then myth only find in the figure of woman. While Signified only found in 2 signs and Denotative Sign found in 5 signs.

\section{Semiotic Elements on Ads 3}

\begin{tabular}{|c|c|c|c|c|c|c|}
\hline Sign & 1 & 2 & 3 & 4 & 5 & 6 \\
\hline $\begin{array}{l}\text { Phrase "DARE TO GO } \\
\text { LONGER AND } \\
\text { STRONGER"(V) }\end{array}$ & + & - & + & + & - & - \\
\hline $\begin{array}{l}\text { Phrase "PANTENE } \\
\text { BEAUTIFUL LENGTH"(V) }\end{array}$ & + & - & + & + & - & - \\
\hline $\begin{array}{l}\text { Sentence "The Pro-V Keratin } \\
\text { protection formulas help } \\
\text { prevent breakage and repair } \\
\text { split ends"(V) }\end{array}$ & + & - & + & + & + & - \\
\hline $\begin{array}{l}\text { Sentence "Joint Pantene to } \\
\text { help woman fighting } \\
\text { cancer"(V) }\end{array}$ & + & - & + & + & - & - \\
\hline $\begin{array}{l}\text { Phrase "HAIR SO } \\
\text { HEALTHY IT SHINES"(V) }\end{array}$ & + & - & + & + & + & - \\
\hline
\end{tabular}

Table 8. Data Semiotic Elements of Advertisement 3 


\begin{tabular}{|c|c|c|c|c|c|c|}
\hline $\begin{array}{l}\text { Phrase } \\
\text { "Facebook.com/Pantene"(NV } \\
\text { ) }\end{array}$ & + & - & + & + & + & - \\
\hline $\begin{array}{l}\text { Letter } \mathrm{ANTENE} \text { ( } \\
\mathrm{V})\end{array}$ & + & - & - & + & - & - \\
\hline $\begin{array}{l}\text { Figure in letter } \\
\text { PNTENE (NV) }\end{array}$ & + & - & - & + & + & - \\
\hline Figure of woman(NV) & + & + & - & + & + & + \\
\hline Symbol $_{(\mathrm{NV})}$ & + & - & + & + & - & - \\
\hline Figure a set of products(NV) & + & + & - & + & + & - \\
\hline TOTAL & 11 & 2 & 7 & 11 & 6 & 1 \\
\hline
\end{tabular}

Notes: $\quad \mathrm{V}=$ Verbal Sign

$\mathrm{NV}=$ Non-Verbal Sign

$+\quad=$ Positive

- $\quad$ Negative

Based on Table 8, there are 11 signs of Signifier, 2 signs of signified, 7 signs of Denotative Sign, 11 signs of Connotative Signifier, 6 signs of Connotative Signified, and 1 sign of Connotative Sign. From the data above, it can be concluded that Signifier and Connotative Signifier are dominate the signs, Denotative Sign is on the second level then followed by Connotative Signified. Then myth only find in the figure of woman. While Signified only found in 2 signs and Connotative Signified found in 6 signs.

After analyzing all advertisements, the writers summarize that Signifier and Connotative Signifier dominate the signs in all advertisements just discussed. Signified, Denotative Sign, Connotative Signifier found in some signs that actually are only emphasizing the Signifier and Connotative Signifier. While Connotative Sign only found in 1 sign in each advertisement, because Connotative Sign in the advertisement which is the high level on order of signification (Chandler, Semiotics the Basics, 2007) depending on the woman, how the woman carrying the expression and make convincing the message of the advertisement.

\section{CONCLUSIONS}

After analyzing three advertisements of Pantene Shampoo, the writers are able to draw the conclusion and summarize the answer to the problems in this research as mentioned in the introduction.

Pantene Shampoo is one of the most popular and best hair care product in this world. It is the one of the brand of $P \& G$. $P \& G$ is a company which produces various of beauty product like Olay, SK II, Downy, Pampers, and Bounty, Pantene Shampoo is one of the best products of this company.

Pantene Shampoo advertisements consist of two signs. They are verbal sign and non-verbal sign. The verbal sign which can be analyzed on the advertisements is the text or the sentence. The texts or sentences are stated explicitly in the advertisements. These signs are known as verbal sign. The sign are stated verbally in the form of texts or sentences. The texts can be in any format, in the level of a word, the level of phrase, or in the sentence level.

Meanwhile, the non-verbal sign is not a word, sentence or text, is more to the picture, symbol and color used in the advertisements. The non-verbal signs are shown implicitly. It distinguishes from the verbal signs (explicitly stated in the form of text, phrase, even sentences). Again, the non-verbal signs must be seen from picture(s) in the advertisements, the symbol used in the advertisements. In addition, the use of color also plays a very important role in conveying the order of significance. As stated in the discussion, that every color has its own characteristics and it conveys different meaning and different purposes when the color itself is applied in an advertisement.

Most of the advertisement in common, specifically these three advertisements just discussed had used the verbal sign and non-verbal sign. The use of them can not be aparted from the purposes of creating the advertisements and the target market. The presence of verbal and non-verbal sign are to reinforce the advertisement's message. The message or the meaning that the advertisers want to deliver to the public, say, prospective buyer of the product, in this case pantene products. Talking about the meaning, these signs have their denotation and connotation meaning which build the myth of the advertisement. The denotation meaning comes from the signifier and signified of the meaning. The connotation meaning comes from the denotation as the signifier and the signified.

The verbal signs in all advertisements are almost have the same meaning, but the non-verbal signs have different meaning in each advertisement. It can be surely stated that the meaning od verbal signs are almost the same because it is explicitly stated and can be understood and crosschecked the meaning by referring to dictionary. In other case, it does not occur to non-verbal signs in an advertisement. Although the non-verbal signs have different meaning in each advertisement, myths of the advertisements are found in the figure of the woman in all advertisements. This informs us as the reader 
that easily the myths are represented by the use of figure in the advertisements. Once again, that this differences of meaning as it is stated implicitly, not explicitly in the advertisments. This differences then opens up to a deeper discussion of every non-verbal signs used in advertisements. This leads the reader to an understanding of myths.

In simpler meaning, myth is believed as a condition in the next specific area or time in early history that motivates or affects the developing of culture in the next specific time. Thus, there are two prospective discussion by the condition - specific area and specific time. It informs not the rationale of using specific color, symbols, and even the figure of a public figure in the advertisement. The specific area here means the target market, considering the culture of the target market too. The specific time leads the reader to an understanding of producing advertisement by considering the right moment and related to the target market.

The myth that the writers get from those three advertisements are closely related to the recent condition of shampoo product, pantene shampoo. For example the data that show the report on the shampoo production function, its beauty factors in every side. The data inform clearly the function of the products. It is said clearly informed because the function is explicitly stated through texts, phrases, or sentences. Those kinds of condition affect the making of advertisements. The persuasiveness of advertisement arouse public market curiosity of the product being advertised. This kind of persuasiveness is more to the non-verbal signs used in the advertisements. Or in short, in the forms of color use, symbol use, and public figures photos use in the advertisements.

Thus, this discussion will inform the reader and is really helpful to the advertisement producers, and alert them to think of all and consider the semiotic elements in their advertisements. The creators of the advertisements have to make it easy to understand by the public or target market of the product. Everyday, there are many advertisements produced, and it opens up wide discussion on the semiotic elements.

\section{REFERENCES}

Akmal, H. (2008). Perbedaan Antara Teori Semiotika Peirce dan Barthes. Jakarta: AlTuras vol.

Berger, J. (1990). Görme Biçimleri, Çev: Yurdanur Salman. İstanbul: Metis Yayınları.
Brown, C. (2012, January).

https://news.pg.com/press-release/pgcorporate-announcements/pantenewelcomes-its-new-girl-zooey-deschanel. Retrieved January 2019, from Pantene Welcomes Its New Girl, Zooey Deschanel: Raven Haired Actress and Musician to Represent Pantene Beautiful Lengths Collection: https://news.pg.com/

Chandler, D. (2007). Semiotics the Basics. London: Routledge.

Chandler, D. (2017). Semiotics for Beginner : Denotation, Connotation, and Myth. Retrieved January 2019, from http://visualmemory.co.uk/daniel/Documents/S4B/sem 06.html: http://visual-memory.co.uk/

Danesi, M. (2007). The Quest for Meaning: A Guide to Semiotic Theory and Practice. Toronto: Toronto University Press.

Global Cosmestic News. (2015). https://globalcosmeticsnews.com/pantenecompany-profile/. Retrieved January 6, 2019, from https:/globalcosmeticsnews.com/

Jamani, K. J. (2011). A Semiotic Discourse Analysis Framework: Understanding Making Meaning in Science Education Context. In Steven C. Hamel (Ed.) Semiotics Theory and Application. New York: Nova Science Publishers, Inc.

Kükürt, R. O. (2016). Semiology and a Semiological Reading of Power Myths in Education. . Kuram Ve Uygulamada Eğitim Bilimleri Educational Sciences: Theory \& Practice. , 2167-2191.

Matikas, P. (2009). Color Perception Psychology, Process and Analysis. New York: Nova Science Publisher.

MSG. (2019). Print Advertising. Retrieved January 6, 2019, from https://www.managementstudyguide.com/p rint-advertising.html:

https://www.managementstudyguide.com/

Oswald, L. R. (2012). Marketing Semiotics Sign. Strategies and Brand Value. New York: Oxford University Press.

Procter \& Gamble. (2019). Share Your Good Hair Day \#PanteneHair. Retrieved January 6, 2019, from www.pantene.com/en-us: www.pantene.com/en-us 
Rose, G. (2001). Visual Methodologies. London: Sage Publications Ltd.

Saussure, F. d. (1985). Genel Dilbilim Dersleri. İstanbul: Birey ve ToplumYayınları.

Schement, R. G. (2002). Encyclopedia of Communication and Information (Volume1 ACA FUN). New York: Macmillan Library Reference.

Sidauruk, Juniato. (2010). Makna Dalam Semantik dan Semiotik. Ilmu Linguistik: Universitas Indonesia. Retrieved January 2019, from https://fdokumen.com/document/uas-3mitos-barthes-prof-okke.html.

Stantons, W. J. (2006). Marketing Research. 3 rd Edition. New Delhi: Tata Mc Graw-Hill publishing company Ltd.

Tsotra, Danai.Marius Janson, Dubravka CecezKecmanovic. (2004). Marketing on the Internet. the Tenth Americas Conference on Information System (p. 2411). New York: Proceedings of the Tenth Americas Conference on Information System. 